\title{
Anatomical investigation of the measurements, shape and arterial irrigation of the adrenal gland in New Zealand rabbits*
}

\section{Investigação anatômica das medidas, forma e irrigação arterial da glândula adrenal em coelhos da raça Nova Zelândia}

\author{
Stephanie Cardoso da Silva, ${ }^{* *}$ Shirley Viana-Peçanha, ${ }^{* *}$ Renata Medeiros- do -Nascimento, ${ }^{* *}$ \\ Carlos Augusto dos Santos Sousa, ${ }^{* * *}$ Paulo Souza- Junior, ${ }^{* * *}$ Marcelo Abidu- Figueiredo**
}

\begin{abstract}
Rabbits have been used as an experimental model in many studies. These studies are important not only for veterinary clinicians, but also for researchers in different fields. The aim of this research was to describe gross morphological measurement, shape and arterial supply of the adrenal glands in healthy New Zealand rabbits. Dissections were performed in 30 adult rabbits, 15 males and 15 females, without macroscopic adrenal pathology. Adrenal measurements were made with a digital caliper: length, width, and thickness. The origin of the adrenal arteries was also determined. Both adrenal glands were localized cranially to the respective kidneys. The mean of the right adrenal gland was $0.88 \mathrm{~cm}$ length, $0.42 \mathrm{~cm}$ width and $0.16 \mathrm{~cm}$ thickness; the left gland measured $0.72 \mathrm{~cm}, 0.46 \mathrm{~cm}$, and $0.17 \mathrm{~cm}$, respectively. The right gland was significantly more elongated than the left $(p=0.0003)$ and the means of the measurements did not differ between sexes. Most of the right adrenal glands had a piriform shape (73.3\%), whereas most of the left gland exhibited a "bean-shaped" aspect (60.0\%). The arterial supply was found to arise from different arteries: lumbar, aorta, renal, caudal mesenteric, and testicular or ovarian. Comparatively, the descriptions of shape, position and arterial irrigation of the adrenal gland in rabbits are similar to those available in rodents. The data from the present investigation will assist in the interpretation of pathological and / or experimental findings in New Zealand rabbits.
\end{abstract}

Keywords: endocrinology, lagomorphs, morphology.

\section{Resumo}

Coelhos têm sido utilizados como modelo experimental em muitos estudos. Esses estudos são importantes não apenas para médicos veterinários, mas também para pesquisadores de diferentes campos. O objetivo desta pesquisa foi descrever as medidas morfológicas macroscópicas, forma e suprimento arterial das glândulas adrenais em coelhos saudáveis da raça Nova Zelândia. As dissecções foram realizadas em 30 coelhos adultos, 15 machos e 15 fêmeas, sem sinais macroscópicos de patologia adrenal. As medidas adrenais foram realizadas com paquímetro digital: comprimento, largura e espessura. A origem das artérias adrenais também foi determinada. Ambas as glândulas adrenais foram localizadas cranialmente nos respectivos rins. A média da glândula adrenal direita foi de $0,88 \mathrm{~cm}$ de comprimento, $0,42 \mathrm{~cm}$ de largura e 0,16 cm de espessura; a glândula esquerda mediu $0,72 \mathrm{~cm}$, $0,46 \mathrm{~cm}$ e $0,17 \mathrm{~cm}$, respectivamente. A glândula direita foi significativamente mais alongada que a esquerda $(p=0,0003)$ e as médias das medidas não diferiram entre os sexos. A maioria das glândulas adrenais direitas tinha uma forma piriforme (73,3\%), enquanto a maioria da glândula esquerda exibia um aspecto em "forma de feijão" (60,0\%). Verificou-se que o suprimento arterial provém de diferentes artérias: lombar, aorta, renal, mesentérica caudal e testicular ou ovariana. Comparativamente, as descrições de forma, posição e irrigação arterial da glândula adrenal em coelhos são semelhantes às disponíveis em roedores. Os dados da presente investigação ajudarão na interpretação de achados patológicos e / ou experimentais em coelhos da raça Nova Zelândia.

Palavras-chave: endocrinologia, lagomorfos, morfologia.

\section{Introduction}

The adrenal gland is composed of two structurally and functionally different tissues that have different developmental origins. Each adrenal gland is composed of an outer cortex and an inner medulla. The adrenal gland is located near the craniomedial border of the kidney. Both adrenal glands are retroperitoneal in position. The adrenal glands play an important role in the endocrine system by secreting catecholamines, mineralocorticoids and glucocorticoids (Dyce et al., 2019).

\footnotetext{
${ }^{*}$ Recebido em 3 de agosto de 2020 e aceito em 4 de setembro de 2020

${ }^{* *}$ Federal Rural University of Rio de Janeiro, Seropédica, Brazil.

${ }^{* * *}$ Federal University of Acre, Rio Branco, Brazil.

${ }^{* * * *}$ Federal University of Pampa, Uruguaiana, Brazil.

Corresponding author: marceloabidu@gmail.com.
} 
The vascularization of the rabbit adrenal gland is an important factor in examining its function, which may involve ligation of its vessels and subsequent adrenalectomy (Muto et al., 1988). In addition, more advanced clinical treatments are required, because exotic animals, including rabbits, have recently become major companion animals (Varga, 2014). Adrenalectomy is performed on rabbits to treat tumors of the adrenal gland (Rose et al., 2016). For experimental or therapeutic surgical procedures involving the adrenal gland, it is essential to have a detailed Oknowledge of the anatomical characteristics of the adrenals, such as precise location, measurements and vascularization.

The advances in biomedical research in the last decades are directly related to the use of animals as an experimental model. Through these animal models it is possible to control and measure the numerous variables that cannot be obtained with humans. They also provide information on animal health and management improvements (Fagundes and Taha, 2004).

Studies from different fields of biology have used rabbit as an experimental model for comprehend adrenal physiology or pathological issues from a long time until today (Brown-Grant et al., 1954; Barnett et al., 1963; Cowie and Watson, 1966; Meng et al., 2019). However, despite its wide use in biomedical research and as a companion animal, some aspects of its gross anatomy are still scarce and require a more detailed description. The aim of this research was to describe the morphological and vascular characteristics of the adrenal gland in New Zealand rabbits.

\section{Material and methods}

The research ethics committee of Rio de Janeiro Federal Rural University approved this study (number 23083.002379/2007-08). Anatomical dissections were performed in 30 adult New Zealand adult rabbit without macroscopic adrenal pathology: 15 males and 15 females with a rostrum-sacral length of $43.07 \pm 2.98 \mathrm{~cm}$ and $41.70 \pm 2.54 \mathrm{~cm}$, respectively.

The animals were obtained from the collections of the Laboratório de Ensino e Pesquisa em Morfologia dos Animais Domésticos e Selvagens do Departamento de Anatomia Animal e Humana, da Universidade Federal Rural do Rio de Janeiro.

For fixation of the specimens, the thorax was first opened and dissected and a urethral catheter number 2 was introduced in its thoracic aorta. The arterial system was then "washed" with $0.9 \% \mathrm{NaCl}$ solution, and fixed with $10 \%$ formalin solution. Next, aqueous solution (1:1 dilution) of Petrolátex S-65 (Refinery Duque de Caxias-REDUC- Petrobras, Duque de Caxias-RJ) was injected together with a dye, xadrez ${ }^{\circledR}$. Finally, the cadavers were immersed in a 500L low density polyethylene box containing $10 \%$ formaldehyde solution to complete the latex fixation and polymerization process. After 7 days of latex injection, the cadavers were washed in running water, and its peritoneal cavity were opened and dissected to demonstrate the adrenal gland, their respective vessels and skeletopy. The rostrum-sacral length of each cadaver was obtained with a flexible tape. Using a digital caliper $(0-150 \mathrm{~mm}, 0.01 \mathrm{~mm}$ resolution, accuracy $\pm 0.02 \mathrm{~mm}$, $\mathrm{Eda}(\mathrm{R})$, adrenal measurements (length, width and thickness) were obtained. According to the shape, the adrenal gland was classified into elliptic, piriformis, bean, rounded or elongated.

The mean and standard deviation of the adrenal measurements were calculated and compared in both sexes and antimeres by the unpaired t test. The relation between the adrenal measures and the rostrum-sacral length (RSL) was calculated by the coefficient of correlation " $r$ " varying between -1 and +1 . A value of $P<0.05$ was considered statistically significant. The data were analyzed using the Graphpad Prism $5 \circledR$ Software.

\section{Results}

Both adrenal glands were localized cranially to the respective kidneys. The right adrenal gland of rabbits measured $0.88 \times 0.42 \times 0.16 \mathrm{~cm}$ and the left $0.72 \times 0.46 \times 0.17 \mathrm{~cm}$, showing that the right gland is significantly more elongated than the left $(p=0.0003)$ (Table 1). The means of the measures did not differ between genders (Table 2). In both males (Table 3 ) and females (Table 4), the average length of the right gland was greater than that of the left, being significant in males $(p<0.01)$.

There was a moderate, negative, significant linear correlation between the width of the left adrenal gland and the rostrum-sacral length only in female's rabbits $(r=-0.57, p=0.03)$. The other measures showed no significant correlation with the rostrumsacral length (Tables 5, 6 and 7).

The right adrenal gland showed a piriform shape in $73 \%$ of rabbits (Figure 1), while in the left gland the bean-shaped format predominated in $60 \%$ of the sample (Table 8 ).

Table 1: Mean and standard deviation of the adrenal gland measurements $(\mathrm{cm})$ of New Zealand rabbits $(\mathrm{n}=30)$, separated by antimers. The $p$-values were obtained by unpaired t test

\begin{tabular}{lccc}
\hline \multirow{2}{*}{ Measurements $(\mathbf{c m})$} & \multicolumn{3}{c}{ Rabbits $(\mathbf{n = 3 0})$} \\
\cline { 2 - 4 } & Right & Left & p-value \\
\hline Adrenal gland length & $0.88 \pm 0.16$ & $0.72 \pm 0.18$ & $<0.01^{*}$ \\
Adrenal gland width & $0.42 \pm 0.12$ & $0.46 \pm 0.11$ & 0.15 \\
Adrenal gland thickness & $0.16 \pm 0.06$ & $0.17 \pm 0.05$ & 0.34 \\
\hline
\end{tabular}

Data expressed as mean and standard deviation. ${ }^{*} \mathrm{p}<0.05$ 
Table 2: Mean and standard deviation of adrenal gland measurements $(\mathrm{cm})$ New Zealand rabbits $(\mathrm{n}=30)$, separated by sex. The $p$-values were obtained by unpaired t test

\begin{tabular}{lccc}
\hline \multicolumn{1}{c}{ Measurement $(\mathbf{c m})$} & $\begin{array}{c}\text { Male } \\
(\mathbf{n}=15)\end{array}$ & $\begin{array}{c}\text { Female } \\
(\mathbf{n = 1 5})\end{array}$ & p-value \\
\hline Length of the right adrenal gland & $0.91 \pm 0.04$ & $0.86 \pm 0.04$ & 0.33 \\
Length of the left adrenal gland & $0.72 \pm 0.02$ & $0.71 \pm 0.06$ & 0.93 \\
Width of the right adrenal gland & $0.40 \pm 0.03$ & $0.45 \pm 0.03$ & 0.27 \\
Width of the left adrenal gland & $0.45 \pm 0.03$ & $0.49 \pm 0.03$ & 0.31 \\
Thickness of the right adrenal gland & $0.16 \pm 0.02$ & $0.16 \pm 0.01$ & 0.75 \\
Thickness of the left adrenal gland & $0.16 \pm 0.01$ & $0.18 \pm 0.01$ & 0.23 \\
\hline
\end{tabular}

Data expressed as mean and standard deviation. ${ }^{*} \mathrm{p}<0.05$

Table 3: Comparison of the adrenal gland $(\mathrm{cm})$ between antimers in males New Zealand Rabbits $(n=15)$

\begin{tabular}{lccc}
\hline \multirow{2}{*}{ Measurements $(\mathrm{cm})$} & \multicolumn{3}{c}{ Male rabbits $(\mathrm{n}=15)$} \\
\cline { 2 - 4 } & Right & Left & p-value \\
\hline Adrenal gland length & $0.91 \pm 0.04$ & $0.72 \pm 0.02$ & $<0.01^{*}$ \\
Adrenal gland width & $0.40 \pm 0.03$ & $0.46 \pm 0.03$ & 0.29 \\
Adrenal gland thickness & $0.39 \pm 0.09$ & $0.17 \pm 0.01$ & 0.76 \\
\hline
\end{tabular}

Data expressed as mean and standard deviation. ${ }^{*} p<0.05$

Table 4: Comparison of the adrenal gland $(\mathrm{cm})$ between antimers in females New Zealand Rabbits $(n=15)$

\begin{tabular}{lccc}
\hline \multirow{2}{*}{ Measurements $(\mathbf{c m})$} & \multicolumn{3}{c}{ Female rabbits (n=15) } \\
\cline { 2 - 4 } & Right & Left & p-value \\
\hline Adrenal gland length & $0.86 \pm 0.04$ & $0.71 \pm 0.06$ & 0.07 \\
Adrenal gland width & $0.45 \pm 0.03$ & $0.49 \pm 0.03$ & 0.31 \\
Adrenal gland thickness & $0.16 \pm 0.01$ & $0.18 \pm 0.01$ & 0.26 \\
\hline
\end{tabular}

Data expressed as mean and standard deviation. ${ }^{*} p<0.05$
Table 5: Coefficient of linear correlation values $(r)$ between the rostrum-sacral length (RSL) and adrenal measurements in New Zealand Rabbits $(n=30)$

\begin{tabular}{lcccc}
\hline \multirow{2}{*}{\multicolumn{1}{c}{ Rabbits $(\mathbf{n = 3 0 )}$}} & \multicolumn{2}{c}{ Right } & \multicolumn{2}{c}{ Left } \\
\cline { 2 - 5 } & $\boldsymbol{r}$ & $\mathbf{p}$-value & $\boldsymbol{R}$ & $\mathbf{p}$-value \\
\hline RSL $x$ adrenal gland length & 0.23 & 0.21 & 0.08 & 0.67 \\
RSL $x$ adrenal gland width & -0.08 & 0.68 & -0.31 & 0.09 \\
RSL $x$ adrenal gland thickness & -0.30 & 0.11 & -0.26 & 0.17 \\
\hline
\end{tabular}

Table 6: Coefficient of linear correlation values $(r)$ between the rostrum-sacral length (RSL) and adrenal measurements in male New Zealand Rabbits $(n=15)$

\begin{tabular}{lcccc}
\hline \multirow{2}{*}{ Male rabbits $(\mathrm{n}=15)$} & \multicolumn{2}{c}{ Right } & \multicolumn{2}{c}{ Left } \\
\cline { 2 - 5 } & $\boldsymbol{r}$ & $\mathbf{p}$-value & $\boldsymbol{r}$ & p-value \\
\hline RSL $x$ adrenal gland length & 0.25 & 0.38 & 0.36 & 0.18 \\
RSL $x$ adrenal gland width & -0.01 & 0.96 & -0.05 & 0.87 \\
RSL $x$ adrenal gland thickness & -0.38 & 0.16 & -0.44 & 0.10 \\
\hline
\end{tabular}

Table 7: Coefficient of linear correlation values $(r)$ between the rostrum-sacral length (RSL) and adrenal measurements in female New Zealand Rabbits $(n=15)$

\begin{tabular}{lcccc}
\hline \multirow{2}{*}{ Female rabbits $(\mathbf{n = 1 5 )}$} & \multicolumn{2}{c}{ Right } & \multicolumn{2}{c}{ Left } \\
\cline { 2 - 5 } & $\boldsymbol{r}$ & $\mathbf{p}$-value & $\boldsymbol{r}$ & $\mathbf{p}$-value \\
\hline RSL $x$ adrenal gland length & 0.14 & 0.61 & -0.03 & 0.92 \\
RSL $x$ adrenal gland width & -0.04 & 0.87 & -0.57 & $0.03^{*}$ \\
RSL $x$ adrenal gland thickness & -0.17 & 0.55 & 0.05 & 0.85 \\
\hline${ }^{*} \mathrm{p}<0.05$ & & & &
\end{tabular}

The arterial supply for adrenal glands arose from different arteries: lumbar, aorta, renal, caudal mesenteric, testicular and ovaric.

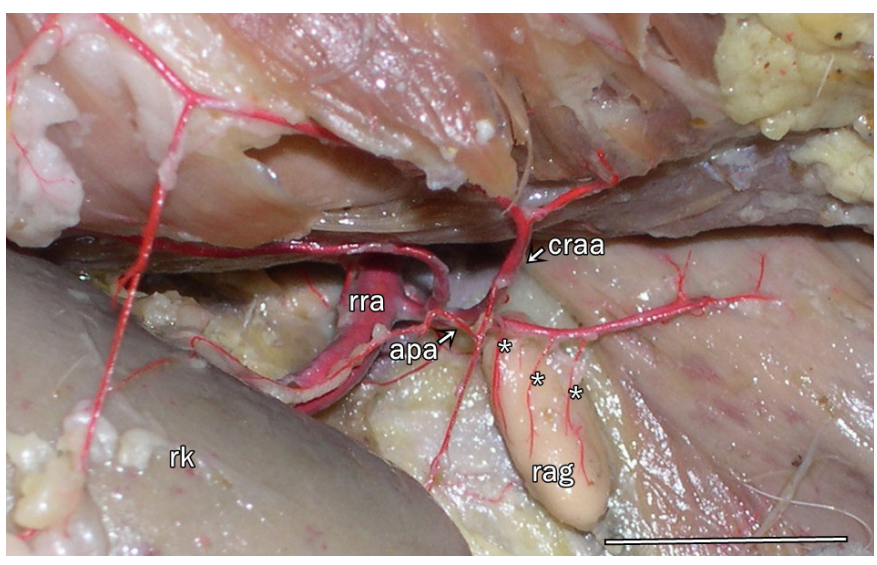

Figure 1: Digital Photomacrography of the lateral view of right adrenal gland and its vascularization. rk - right kidney, rra - right renal artery, apa - abdominal phrenic artery, craa - cranial abdominal artery, ${ }^{*}$ adrenal branches, rag - right adrenal gland. Scale bar $1 \mathrm{~cm}$. 
Table 8: Absolute and percentual frequencies of the shapes of the right and left adrenal glands in male and female New Zealand Rabbits

\begin{tabular}{lcccccc}
\hline \multirow{2}{*}{$\begin{array}{c}\text { Adrenal } \\
\text { shape }\end{array}$} & \multirow{2}{*}{ Right $(\mathrm{n}=\mathbf{3 0})$} & Left $(\mathrm{n}=\mathbf{3 0})$ & Male $(\mathrm{n}=15)$ & Female $(\mathrm{n}=15)$ & Male $(\mathrm{n}=15)$ & Female $(\mathrm{n}=15)$ \\
\hline Elliptic & - & $04(13.3 \%)$ & - & - & $02(13.3 \%)$ & $02(13.3 \%)$ \\
Piriformis & $22(73.4 \%)$ & & $08(53.3 \%)$ & $14(93.3 \%)$ & - & - \\
"Bean" & $04(13.3 \%)$ & $18(60.0 \%)$ & $03(20.0 \%)$ & $01(6.7 \%)$ & $09(60.0 \%)$ & $09(60.0 \%)$ \\
Rounded & & $03(10.0 \%)$ & - & - & - & $03(20.0 \%)$ \\
Elongated & $04(13.3 \%)$ & $05(16.7 \%)$ & $04(26.7 \%)$ & - & $04(26.7 \%)$ & $01(6.7 \%)$ \\
\hline
\end{tabular}

\section{Discussion}

\section{Measures}

The average length of the right adrenal gland $(0.88 \mathrm{~cm})$ was greater than that of the left $(0.72 \mathrm{~cm})$, especially in males, with no difference in the other measurements. Barone and Simoens (2010) generically described the adrenal glands of rabbits measuring between 0.7 to $0.8 \mathrm{~cm}$ in length, which was compatible with the findings of the present study.

Banzato et al. (2014) performed an abdominal ultrasound study in rabbits and did not observe statistical differences in the measurements obtained in the adrenal glands. A significant positive correlations were detected between bodyweight and the ultrasonographic measurements of the cranio-caudal length of the adrenal glands. In the present study, there was a negative simple linear correlation between the rostro-sacral length and the width of the left adrenal gland, but only in female rabbits ( $r$ $=-0.5723 ; p=0.03)$.

Despite the lack of studies on lagomorphs, in the rodent Galea spixii right adrenal glands were described as largest (Santos et al. 2016), similar to the rabbits of the present study. However, in Hystrix cristata the left glands were the largest (Ylmaz; Girgin, 2005). In the other hand, adrenal glands of female Cuniculus paca were larger than males (Garcia-Filho et al. 2014), different from New Zealand rabbits. By means of ultrasound, it was observed that the right adrenal glands were larger in both sexes and females had average larger glands (Banzato et al., 2014).

\section{Shape}

Although most of the right adrenal glands showed a piriform shape and the left a bean-shaped format, some glands exhibited elongated, rounded, or elliptic shapes. By abdominal ultrasound in rabbits, the shape of both right and left adrenal glands ranged from ovoid to almost round (Banzato et al., 2014).

The definition of the format may be dependent of subjective inferences. In Gallea spixii, the right adrenal had a more irregular shape than the left and, predominantly, the right gland had a pyramidal shape, while the left had an elongated shape and more homogeneous formats (Santos et al., 2016). However, the left gland had a more consistent format among individuals in the rabbits of this present investigation. In Cuniculus paca, it was observed only the elongated shape in both adrenals Garcia-Filho et al (2014). In Hystrix cristata, both glands were described as flat (Yilmaz and Girgin 2005). In Rattus norvegicus, both adrenal glands have been described as ovoids (Benzato et al. 2014).

\section{Holotopy}

In the rabbits of this present study, the adrenal glands were always cranially located. An abdominal ultrasound study in rabbits observed both the right and the left adrenal glands were located cranially but also medially to the corresponding kidney (Banzato et al., 2014). The right gland is closer to the kidney than the left in rabbits (Barone and Simoens, 2010), which was not a rule in the sample of this present investigation.

In the rodents, Rattus norvegicus and Cuniculus paca have adrenal glands localized immediately cranial to the cranial pole of the corresponding kidneys (Banzato et al., 2014; Garcia-Filho et al., 2014). However, in Hystrix cristata and Galea spixii, both adrenal glands were craniomedially associated with the cranial poles of the kidneys and the right adrenal was most cranially positioned in relation to the left (Yilmaz and Girgin, 2005; Santos et al., 2016).

\section{Arterial supply}

In the present research the arterial supply for adrenal gland arose from lumbar, aorta, renal, caudal mesenteric and testicular or ovarian arteries. Similar findings were also reported in rabbits in which the arterial supply to the adrenal gland came from the caudal phrenic, cranial abdominal, renal and the abdominal aorta arteries (Kigata and Shibata, 2018). In another lagomorph, Lepus europaeus, the arterial supply for adrenal gland arose from abdominal cranial artery, renal artery, phrenic caudal artery, abdominal aorta and celiac artery (Machado et al., 1999).

In rodents, the right adrenal gland of Dasyprocta aguti was irrigated from abdominal phrenic, dorsal renal, extrahilar renal, caudal phrenic and cranial abdominal and caudal abdominal arteries, while the left adrenal gland is irrigated from branches coming from abdominal phrenic, dorsal branches of the renal, extrahilar renal, caudal phrenic, caudal abdominal and cranial mesenteric arteries (Neves et al., 2007). In Rattus norvegicus, the irrigation arose mainly from the caudal phrenic, renal arteries and the abdominal aorta, and rarely from the cranial phrenic artery (Kigata and Shibata, 2018). In Myocastor coypus, the right adrenal gland was supplied by branches of the caudal phrenic, right cranial abdominal, right renal, first lumbar, and abdominal aorta arteries; the left adrenal gland was supplied by branches from the renal, abdominal aorta, cranial abdominal and second lumbar arteries (Machado et al., 2002). 


\section{Conclusions}

In New Zealand rabbits, the mean length of the adrenal gland is asymmetric because right glands are significantly more elongated. The right adrenal glands tend to have a piriform shape and the left gland a "bean-shaped" aspect. The arterial supply was mixed from different arteries nearby the gland. This data will assist in the interpretation of clinical, pathological and experimental findings, as well as for comparative analysis.

\section{Acknowledgment}

National Council of Technological and Scientific Development (CNPq), Rio de Janeiro State Research Foundation (FAPERJ) and Coordination of Superior Level Staff Improvement (CAPES) Finance Code 001.

\section{References}

BANZATO, T.; BELLINI, L.; CONTIERO, B.; MARTIN, A.; BALIKÇI, S.; ZOTTI, A. Abdominal anatomic features and reference values determined by use of ultrasonography in healthy common rats (Rattus norvegicus). American Journal of Veterinary Research. v. 75, n. 1, p. 67-76, 2014. Available in: https://doi. org/10.2460/ajvr.75.1.67.

BARNETT, E.V.; DUMONDE, D.C.; GLYNN, L.E. Induction of autoimmunity to adrenal gland. Immunology. v. 6 , n. 4, p. 382-402, 1963. Available in: https://dx.doi. org/10.1136\%2Fbmj.4.5680.382-a.

BARONE, R.; SIMOENS, P. Glandes endocrines. In: BARONE, R.; SIMOENS, P. (eds.) Anatomie Comparée des mamifères domestiques. Paris: Vigot, 2010, p. 385-458.

BROWN-GRANT, K., HARRIS, G.W., REICHLIN, S. The influence of the adrenal cortex on thyroid activity in the rabbit. The Journal of physiology. v. 126, n. 1, p. 41-51, 1954. Available in:

https://doi.org/10.1113/jphysiol.1954.sp005190.

COWIE, A.T.; WATSON, S.C. The adrenal cortex and lactogenesis in the rabbit. Journal of Endocrinology. v. 35, n. 2, p. 213-214, 1966. Available in: https://doi.org/10.1677/joe.0.0350213.

DYCE K.M.; SACK, W.O.; WENSING, C.J. Tratado de Anatomia Veterinária. 5 ed. Rio de Janeiro: Elsevier, 2019.

FAGUNDES, D.J., TAHA, M.O. Modelo animal de doença: critérios de escolha e espécies de animais de uso corrente. Acta Cirurgica Brasileira. v. 19, n. 1, p. 59-65, 2004. Available in: https://doi.org/10.1590/S0102-86502004000100010.

GARCIA-FILHO, S.,CARVALHO, A.E.G.F; MARTINS, L., MARTINS LEAL, L., PACHECO, M.; FERNANDES MACHADO, M. Morfologia da glândula adrenal da paca (Cuniculus paca, L. 1766). Biotemas. v. 27, n. 2, p. 163-170, 2014. Available in: https://doi.org/10.5007/2175-7925.2014v27n2p163.

KIGATA, T.; SHIBATA, H. Arterial supply to the rabbit adrenal gland. Anatomical Science International. v. 93, n. 4, p. 437-448, 2018. Available in: https://doi.org/10.1007/s12565-018-0433-2.

MACHADO, G.V.; ROMAGNOLLI, P.; SOUZA, J.R.; TURQUETI, V.S.; ULIANA, S.M.; SILVA, M.H. Suprimento arterial para as glândulas adrenais no ratão do banhado (Myocastor coypus, Molina, 1782). Archives of Veterinary Science. v. 7, n. 2, p. 9-14, 2002.
MACHADO, G.V., SILVA, F.O.C., MIGLINO, M.A., SANTOS, T.C., ANDRIOLI, L.G. Suprimento arterial para as glândulas adrenais em Lepus europaeus Pallas, 1778 - Lagomorpha: Mammalia. Arquivo de Ciência Veterinária e Zoologia da UNIPAR. v. 2, n. 1, p. 23-27, 1999

MENG, L.B.; YANG-FAN, Z.; MENG-JIE, S.; MENG, Z.; RUOMEI, Q.I.; ZE-MOU, Y.; PENG, G.; QIAN-WEI, Z.; TAO, G. Computer-assisted prediction of atherosclerotic intimal thickness based on weight of adrenal gland, interleukin- 6 concentration, and neural networks. Journal of International Medical Research. v. 30, n.0, p. 1 - 12, 2019. Available in: https://doi. org/10.1177/0300060519839625.

MUTO, S.; SANSOM, S.; GLEBISCH, G. Effects of a high potassium diet on electrical properties of cortical collecting ducts from adrenalectomized rabbits. Journal of Clinical Investigation. $v$. 81, n.2, p. 376-380, 1988.

NEVES, W.C.; FILHO, M.F.C.; CARVALHO, M.A.M.; ARRIVABENE, M.; MENEZES, D.J.A. Irrigação das glândulas adrenais em cutia dourada (Dasyprocta aguti, Rodentia) Revista da FZVA. v. 14, n. 2, p. 165-174, 2007. Available in: http://dx.doi. org/10.1590/0100-3984.2013.1762.

ROSE, J.B.; STEFFEY, M.A.; CHEN, V.S.; HARVEY, C. Adrenalectomy and nephrectomy in a rabbit (Oryctolagus cuniculus) with adrenocortical carcinoma and renal and ureteral transitional cell carcinoma. Journal of Exotic Pet Medicine. v. 25, v. 4, p. 332-341, 2016. Available in: https://doi.org/10.1053/j. jepm.2016.06.010.

SANTOS, A.C., VIANA, D.C., BERTASSOLI, B.M., VASCONCELOS, B.G., OLIVEIRA, D.M., RICI, R.E.G., OLIVEIRA, M.F., MIGLINO, M.A., ASSIS-NETO, A.C. Adrenal glands of Spix's yellow-toothed cavy (Galea spixii, Wagler, 1831): morphological and morphometric aspects. Brazilian Journal of Biology. v. 76, n.3, p. 645-655, 2016. Available in: https://doi. org/10.1590/1519-6984.23514.

VARGA, M. Textbook of rabbit medicine. 2 ed. Butterworth Heinemann, Oxford, 2014.

YILMAZ, S., GIRGIN, A. Light and electron microscopic observations on the structure of the porcupine (Hystrix cristata) adrenal gland. Veterinarski Arhiv. v. 75, n. 3, p. 265-272, 2005. 